\title{
The genetic causes of infertility in patients with oligozoospermia and azoospermia in Turkish population
}

\section{Türk popülasyonunda oligozoospermi ve azospermi hastalarında infertilitenin genetik nedenleri}

\author{
Yavuz Onur Danacioglu ${ }^{1}$, Mustafa Gurkan Yenice ${ }^{1}$, Fatih Akkas ${ }^{2}$, Mustafa Soytas ${ }^{3}$, Serhat Seyhan ${ }^{4}$, Ali Ihsan Tasci \\ 1 University of Health Sciences Bakirkoy Dr. Sadi Konuk Training and Research Hospital, Department of Urology, Istanbul, Turkey \\ 2 University of Health Sciences Erzurum Training and Research Hospital, Department of Urology, Erzurum, Turkey \\ 3 Medipol University, Department of Urology, Istanbul, Turkey \\ 4 University of Health Sciences Bakirkoy Dr. Sadi Konuk Training and Research Hospital, Department of Medical Genetics, Istanbul, Turkey
}

Submitted: 2020-12-02

Accepted: 2021-03-10

Correspondence
Yavuz Onur Danacioğlu
Zuhuratbaba Mah, Dr. Tevfik Saglam Cd
No:11, 34147 Bakırkoy,
Istanbul / Turkey
e-mail: dr_yonur@hotmail.com
T: +90 5322935673
F: +902124147280

ORCID
Y.O.D.
$\begin{array}{ll}\text { M.G.Y. } & 0000-0002-3170-062 X \\ \text { F.A. } & 0000-0002-5813-3565 \\ \text { M.S. } & 0000-0002-4560-7426 \\ \text { S.S. } & 0000-0002-3474-3510 \\ \text { A.I.T. } & 0000-0002-7785-2995\end{array}$

\section{(1) \$}

This work is licensed under a Creative Commons Attribution-NonCommercial 4.0 International License.

\section{Özet}

Amaç: Genetik bilimindeki ilerlemeler ve yardımcı üreme tekniklerindeki gelişmeler, infertilitenin genetik nedenlerine odaklanmamızı sağlamaktadır. Bu çalışmada, sex kromozomu anöploidisi ve Y kromozom mikrodelesyonları açısından genetik anormallikleriaraştırmayı amaçladık.

Gereç ve Yöntemler: Azospermi veya şiddetli oligozoospermi ( $\leq 5$ milyon spermatozoa $/ \mathrm{ml}$ ) olan toplam 350 hasta analiz edildi. Hastalar genel muayene ve laboratuvar değerlendirmesi sonrası, karyotip ve $\mathrm{Y}$ kromozom mikrodelesyonu açısından değerlendirildi.

Bulgular: Non-obstrüktif azospermi (NOA) olan toplam 225 infertil erkek ve oligozoospermi olan 125 infertil erkek çalışmaya dahil edildi. Genel sitogenetik anomali oranı\% 16 idi. Üç yüz elli vakanın 32'sinde (\% 9,1) kromozom değişiklikleri tespit edildi. En sık görülen genetik anomali 47, XXY (Klinefelter sendromu KS) idi ve insidans NOA grubunda \% 11.5 ve oligozoospermi grubunda \% 3,2 idi. Y kromozom mikrodelesyonu 24 (\% 6.8) hastada tespit edildi ve benzer șekilde NOA grubunda oligozoospermi grubuna göre daha sık görüldü (\% 9.3 vs \% 2.4, sirasıyla).

Sonuç: İnfertilitenin şiddeti ile birlikte genetik nedenlerin görülme sıklığı artmaktadır. Sonuç olarak, yardımcı üreme tekniklerinin kullanılmasindan önce genetik tarama ve uygun genetik danışmanlığa ihtiyaç duyulmaktadır.

Anahtar Kelimeler: azospermi, kromozom, infertilite, microdelesyon, oligozoospermi

\section{Abstract}

Objective: Advances in the science of genetics and the development of assisted reproductive techniques focus on the genetic causes of infertility. The aim of this research is to reveal genetic abnormalities in terms of sex chromosome aneuploidy and $\mathrm{Y}$ chromosome microdeletions.

Material and Methods: A total of 350 patients with azoospermia or severe oligozoospermia were selected. After general examination of the patients and laboratory investigations were performed, cartoypes and $\mathrm{Y}$ chromosome microdeletions were examined.

Results: A total of 225 infertile men with non-obstructive azoospermia (NOA) and 125 infertile men with oligozoospermia were enrolled into the study. The overall cytogenetic anomaly rate was $16 \%$. Chromosomal changes were detected in 32 of 350 (9.1\%) cases. The most common genetic anomaly was 47 , XXY (Klinefelter syndrome) and the incidence was $11.5 \%$ in NOA group. This rate was $3.2 \%$ in oligozoospermia group. Y chromosome microdeletions were detected in $24(6.8 \%)$ patients and similarly, it was observed more frequently in the NOA group than in the oligozoospermia group.

Conclusion: The incidence of genetic causes have been increasing with the severity of infertility. As a result, genetic screening and appropriate genetic counseling are needed before the use of assisted reproductive techniques.

Keywords: azospermia, chromosome, infertility, microdeletion, oligozoospermiaage 


\section{INTRODUCTION}

Infertility is considered if the fertilization does not occur in spite of unprotected regular sexual intercourse for one year (1). Infertility is a health problem, which affects $15 \%$ of the couples, and almost one-half of infertility caused male-related factors or in combination with female related fertility disorders $(1,2)$. Azoospermia is the absence of the sperms in the semen analysis and oligozoospermia $(<5 \times 106$ spermatozoa $/ \mathrm{ml})$ is defined as the low sperm count in the ejaculate. Infertility in male patients can be occured by a variety of factors, such as varicosel, antisperm antibodies, infection, spermatic duct obstruction, cryptorchidism, endocrine disorders, testicular trauma, esticular cancer, systemic diseases, retrograde ejaculation, etc (2). Except those cases, in $30-40 \%$ of male infertile patients that are presented to as idiopathic, genetic abnormality can be considered (3). The most common genetic cause of male infertility is the chromosomal anomalies and is encountered in $5 \%$ of all cases. This rate increases up to $15 \%$ in azoospermic males (4). The second most common genetic cause of male infertility is $\mathrm{Y}$ chromosome microdeletions, which can't be detected with cytogenetic methods (5). In this study, we evaluated the genetic causes in patients with nonobstructive azoospermia and severe oligozoospermia in infertile males.

\section{MATERIAL AND METHODS}

In this cross-sectional study, after obtaining the ethical approval (2018/01), a total of 350 patients, who admitted to the division of the Andrology from Urology department of University of Health Sciences Bakirkoy Dr. Sadi Konuk Training and Research Hospital due to infertility between January 2015 and January 2017. All participants signed an informed consent form for the use of their blood sample in the study and all records were required to be kept confidential. Patients, who had a semen volume less than $2 \mathrm{cc}$ in the spermiogram analysis, underwent transrectal ultrasound examination for obstructive azoospermia and those with obstructive azoospermia were excluded from the study. The patients had non-obstructive azoospermia (NOA) and severe oligozoospermia in their semen analyses, were analyzed retrospectively. Patients were divided into groups according to sperm count following detailed physical examination and hormonal tests which was performed by a specialist. Semen analyses (motility, sperm concentration and morphology) were performed according to the World Health Organization Guidelines (6). Following the examinations, patients, who had idiopathic azoospermia and severe oligozoospermia ( $\leq 5$ million sperm $/ \mathrm{ml}$ ) with an age between 20 and 45 years were determined. Light microscopic evaluation of sperm motility, concentration, morphology and viability and was performed (6). Specimens originally considered as azoospermic were centrifuged (1000 $\mathrm{g}$ for $20 \mathrm{~min}$ ) and the pellets were examined for spermatozoa, before confirming azoospermia (7). The diagnosis of azospermia and oligozoospermia was confirmed by two spermiograms examined at least 15 days apart following 3 days of sexual abstinence. Blood samples of the patients were taken into tubes containing ethylenediaminetetraacetic acid (EDTA). DNA was isolated from the peripheral blood samples with the DNA isolation device (MagNA Pure Compact System). Karyotype analysis was performed on lymphocyte cultures stimulated by phytohaemagglutinin adapting methodology (8).

For the Y chromosome microdeletion analysis, the amplification of the relevant regions was carried out with the multiplex PCR method using the SRY and ZFY regions and STS sequence-tagged site (STS) primers. Following the multiplex PCR process, the microdeletions in $\mathrm{AZFa}, \mathrm{AZFb}$ and $\mathrm{AZFc}$ regions and SRY and ZFY regions were investigated with the agarose gel electrophoresis.

\section{Statistical Analysis}

Data analysis was performed using the SPSS version 16.0 software package. The continuous variables are presented as mean \pm standard deviation. The frequencies of categorical variables were compared using Pearson Chi-Square test. Statistical significance was considered when $\mathrm{p}$ value was $<0.05$.

\section{RESULTS}

A total of 350 infertile men were evaluated, 225 (64.2\%) of whom were azoospermic males and 125 
(35.7\%) oligozoospermic males. The mean age of the NOA and oligozoospermic patients were calculated as $33.4 \pm 4.3$ years and $34.6 \pm 4.8$ years, respectively. The overall incidence of cytogenetic abnormalities was $16 \%$. Chromosomal abnormalities were detected in $32(9.1 \%)$ of 350 cases. Numerical and structural chromosomal abnormalities are summarized in Table 1. Four patients in the oligozoospermia group had Kleinfelter syndrome (47,XXY; KS) syndrome (3.2\%). In NOA group, twenty-four (11.5\%) patients had KS; two $(0.88 \%)$ patients had $46, \mathrm{XY} / 47, \mathrm{XXY}$; one $(0.44$ $\%)$ patient had $46, \mathrm{XY} / 45 \mathrm{XO}$ and one $(0.44 \%)$ patient had 46,XX. In oligozoospermia group, 121 had normal karyotype (96.8\%), 4 patients had abnormal karyotype (3.2\%). Among NOA group, 197 had normal karyotype (87.6\%), 28 had abnormal karyotype (12.4\%). While the mean age of KS patients in the oligozoospermia group was $28 \pm 4$ years, in NOA goup it was $27 \pm 6$ years. As semen parameters deteriorated, the chromosomal abnormality frequency increased and statistically significant difference was found ( $\mathrm{p}=0.004$; Table 1$)$. In all patients groups, the incidence of KS (47,XXY) was $8 \%(n=28)$ and it was the most frequent abnormality. In oligozoospermia and NOA groups, KS frequency were $3.2 \%$ and $11.5 \%$ respectively ( $n=4$ vs $n=24$, respectively). The overall incidence of $\mathrm{Y}$ chromosome microdeletion was $6.8 \%$. Three (\%2.4) patients in oligozoospermia group and twenty-one (9.3\%) patients in NOA group, Y chromosome microdeletions were detected. It was statistically significant difference between oligozoospermia and NOA groups $(p=0.007)$. The most frequent region with deletions was the AZFc region. Based on molecular screening of the AZF region, a total of 24 AZF microdeletions were found: 1 in $\mathrm{AZFa}+\mathrm{b}+\mathrm{c}, 2$ in $\mathrm{AZFa}, 2$ in $\mathrm{AZFb}, 3$ in $\mathrm{AZFb}+\mathrm{c}$, and 16 in AZFc (Table 2).

Table 1. Distribution of normal and abnormal karyotypes in the patients included in the study

\begin{tabular}{l|l|l|l}
\hline Karyotype & \multicolumn{1}{|c|}{ Reasons of male infertility } & Total \\
\hline & NOA (n, \%) & Oligozoospermia (n, \%) & $(\mathbf{n = 3 5 0 )}$ \\
\hline Normal $(46, \mathrm{XY})$ & $197(61.9 \%)$ & $121(38.1 \%)$ & 318 \\
\hline Abnormal & & & 28 \\
KS (47,XXY) & $24(85.7 \%)$ & $4(14.3 \%)$ & 2 \\
Mozaic KS & $2(100 \%)^{1}$ & & 2 \\
$\begin{array}{l}\text { Other sex chromosome mosaicism 45,X0 } \\
(\mathrm{n}=1) \text { and 46,XX (n=1) }\end{array}$ & $2(100 \%)$ & & \\
\hline
\end{tabular}

KS: Kleinfelter syndrome; NOA: Non-obstructive azoospermia;

Table 2. Y chromosome microdeletions in infertile cohort

\begin{tabular}{l|l|l|l}
\hline Y chromosome & \multicolumn{1}{|c|}{ Reasons of male infertility } & Total \\
\hline & NOA (n; $)$ & Oligozoospermia (n; \%) & $\mathbf{3 5 0}$ \\
\hline Normal & $204(90,6 \%)$ & $122(97,6 \%)$ & \\
Deleted & $21(9,3 \%)$ & $3(2,4 \%)$ & 24 \\
AZFa & $2(0,8 \%)$ & 0 & 2 \\
AZFb & $2(0,8 \%)$ & 0 & 2 \\
AZFc & $13(5,7 \%)$ & $3(2,4 \%)$ & 16 \\
AZFbc & $3(1,3 \%)$ & 0 & 3 \\
AZFabc & $1(0,4 \%)$ & 0 & 1 \\
\hline
\end{tabular}

NOA: Non-obstructive azoospermia; 


\section{DISCUSSION}

Among numerous etiologic factors, genetic disorders plays a primary key role in male infertility with abnormal semen parameters. Spermatogenesis is regulated by a number of genes on the $\mathrm{Y}$ chromosome and by autosomes that act at different stages of germ cell development (9). In the present study, the frequency of chromosomal abnormality was founded as $9.1 \%$. These findings are very similar to those reported in earlies studies (10). In the literature there are many studies about chromosomal abnormality rate from diffrent countries which were reported as $6.2-12.6 \%(11,12)$. Consistent with other clinical studies, KS was found to be the most common anomaly in this study (11, 13). In the current study, 26 of the $30 \mathrm{KS}$ patients were azospermic (24 patients with 47, XXY and 2 patients with mosaicism). While the mean age of KS patients in the oligozoospermia group was $18 \pm 4$ years and it was $27 \pm 6$ years in NOA group. This finding is consistent with germ cell degeneration and early-onset progressive testicular insufficiency is $\mathrm{KS}$ patients $(1,2,14,15)$.

Excessive $\mathrm{X}$ chromosome is paternal in $50-60 \%$ of cases and maternal in 40-50\% of cases (16). Epidemiological studies have shown that the incidence of KS is gradually rising and it is thought to be related with increasing father age (17). However, only $25 \%$ of all cases with $\mathrm{KS}$ are diagnosed and followed up clinically. However, in recent years, patients with KS have significant health problems not only with infertility but also with high morbidity $(70 \%)$ and mortality $(50 \%)(17,18)$. It is important that the patients are diagnosed early in puberty and the management of the disease is considered as soon as possible. In KS patients, secondary sex characteristics become apparent with testosterone replacement therapy. Depressive mood of the patient disappears and self-confidence increases. In general, patients with KS are accepted as infertile, however assisted reproductive techniques may provide fertilization. These patients may also have children by means of sperm cryopreservation, testicular sperm extraction (TESE), micro-TESE and intracytoplasmic sperm injection (ICSI). Freezing of spermatogonial stem cells or storage of testicular tissue are yet experimental treatments (19).

Y chromosome microdeletions are the second most common cause of male infertility (20). Eth- nic and regional factors have been considered as the main parameters affecting diversity and prevalence of these microdeletions (21). An international analysis of a large dataset revealed that the prevalence of Yq microdeletions was between $7 \%$ and 10\% (21). The incidence of the $\mathrm{Y}$ chromosome microdeletion in the Turkish population was investigated by several authors (1.3-9.6\%) (4, 22-24). In our study, the frequency of $Y$ chromosome microdeletion was calculated as $6.8 \%$. These frequency variations may be due to the genetic variation in different populations especially in $\mathrm{Y}$ chromosome specific haplotypes, genetic background, environmental factors, and different types of primers for AZF-related microdeletions. Furthermore, the population size, patient selection based on the etiology and severity of spermatogenesis defects, and the regional differences can be considered as the possible reasons for these frequency variations. Mirfakhraie et al. reported a higher AZFb (66.67\%) microdeletion frequency compared to the AZFc (41.67\%) region in general Iranian population (25). It was stated that although AZFc deletion affects the spermatogenesis, it does not always cause infertility. Sperm may be obtained with TESE and fertilization may occur in azoospermic males with AZFc deletion. Germ cells are totally lost in cases with complete deletions of AZFa and $\mathrm{AZFb}$ regions. TESE and ICSI will fail in these cases. It was reported that the probability of sperm detection with TESE in partial AZFb deletion was 50\% (26). In cases with Yq microdeletion, who underwent assisted reproductive techniques, couples should be informed that the microdeletion will be transferred to the male children and consequently these children may also have spermatogenesis disorders.

The retrospective character of the study and the lack of knowledge of treatment methods applied to the patients and paternity rates during follow-up are the limiting factors.

\section{CONCLUSION}

Genetic analysis and consultation should be considered before the implementation of the assisted reproductive techniques, when chromosomal anomalies and $\mathrm{Y}$ chromosome microdeletions were detected in infertile males. 


\section{Conflict of Interest}

The authors have no conflicts of interest to declare.

\section{Financial Disclosure}

The authors declared that this study has received no financial support.

\section{Ethical Approval}

The study was approved by the Ethics Committee of Bakırkoy Dr.Sadi Konuk Training and Research Hospital (Approval number: 2018-01-05) (Date: 2018, Jan 8). The study protocol conformed to the ethical guidelines of the Helsinki Declaration.

\section{REFERENCES}

1. Hopps C, Mielnik A, Goldstein M, Palermo G, Rosenwaks Z, Schlegel P. Detection of sperm in men with Y chromosome microdeletions of the AZFa, AZFb and AZFc regions. Human reproduction 2003;18:1660-5.

2. De Kretser D, Baker H. Infertility in men: recent advances and continuing controversies. The Journal of Clinical Endocrinology \& Metabolism 1999;84:3443-50.

3. Krausz C, Riera-Escamilla A. Genetics of male infertility. Nature Reviews Urology 2018;15:369-84.

4. Balkan M, Tekes S, Gedik A. Cytogenetic and Y chromosome microdeletion screening studies in infertile males with Oligozoospermia and Azoospermia in Southeast Turkey. Journal of assisted reproduction and genetics 2008;25:559-65.

5. Özdemir TR, Özyılmaz B, Çakmak Ö, Kaya ÖÖ, Köse C, Kırbıyı Ö, et al. Evaluation of chromosomal abnormalities and Y-chromosome microdeletions in 1696 Turkish cases with primary male infertility: A single-center study. Turkish journal of urology 2020;46:95.

6. Organisation WH. WHO laboratory manual for the examination of human semen and sperm-cervical mucus interaction: Cambridge university press; 1999.

7. Palermo GD, Colombero LT, Hariprashad JJ, Schlegel PN, Rosenwaks Z. Chromosome analysis of epididymal and testicular sperm in azoospermic patients undergoing ICSI. Human Reproduction 2002;17:570-5.

8. Barch MJ, Barch, Knutsen, Spurbeck. AGT Cytogenetics Laboratory Manual: Lippincott Williams \& Wilkins Philadelphia NY; 1997.
9. Dada R, Gupta N, Kucheria K. Cytogenetic and molecular analysis of male infertility. Cell biochemistry and biophysics 2006;44:171-7.

10. Quilter CR, Svennevik EC, Serhal P, Ralph D, Bahadur G, Stanhope R, et al. Cytogenetic and Y chromosome microdeletion screening of a random group of infertile males. Fertility and sterility 2003;79:301-7.

11. Nakamura Y, Kitamura M, Nishimura K, Koga M, Kondoh $\mathrm{N}$, Takeyama M, et al. Chromosomal variants among 1790 infertile men. International Journal of Urology 2001;8:49-52.

12. Yoshida A, Miura K, Shirai M. Cytogenetic survey of 1,007 infertile males. Urologia internationalis 1997;58:166-76.

13. Elghezal H, Hidar S, Braham R, Denguezli W, Ajina M, Saâd A. Chromosome abnormalities in one thousand infertile males with nonobstructive sperm disorders. Fertility and sterility 2006;86:1792-5.

14. Aksglaede L, Juul A. Testicular function and fertility in men with Klinefelter syndrome: a review. Eur J Endocrinol 2013;168:R67-76.

15. Lin YM, Huang WJ, Lin JSN, Kuo PL. Progressive depletion of germ cells in a man with nonmosaic Klinefelter's syndrome: optimal time for sperm recovery. Urology 2004;63:380-1.

16. Peters $\mathrm{O}$, King WA. The detection of female cell activity in male sex chromosome chimeric Rideau Arcott sheep, using the Xist gene product as a marker. SURG Journal 2008;1:20-5.

17. Bojesen A, Juul S, Gravholt CH. Prenatal and postnatal prevalence of Klinefelter syndrome: a national registry study. The Journal of Clinical Endocrinology \& Metabolism 2003;88:622-6.

18. Swerdlow AJ, Higgins CD, Schoemaker MJ, Wright AF, Jacobs PA, Group UKCC. Mortality in patients with Klinefelter syndrome in Britain: a cohort study. The Journal of Clinical Endocrinology \& Metabolism 2005;90:6516-22.

19. Fainberg J, Hayden RP, Schlegel PN. Fertility management of Klinefelter syndrome. Expert Review of Endocrinology \& Metabolism 2019;14:369-80.

20. Massart A, Lissens W, Tournaye H, Stouffs K. Genetic causes of spermatogenic failure. Asian journal of andrology 2012;14:40

21. Colaco S, Modi D. Genetics of the human Y chromosome and its association with male infertility. Reproductive biology and endocrinology 2018;16:14. 
22. Sargın CF, Berker-Karaüzüm S, Manguoğlu E, Erdoğru T, Karaveli Ş, Gülkesen KH, et al., editors. AZF microdeletions on the $\mathrm{Y}$ chromosome of infertile men from Turkey. Annales de genetique; 2004: Elsevier.

23. Akin H, Onay H, Turker E, Ozkinay F. Primary male infertility in Izmir/Turkey: a cytogenetic and molecular study of 187 infertile Turkish patients. Journal of assisted reproduction and genetics 2011;28:419-23.

24. Küçükaslan AŞ, Çetintaş VB, Altıntaş R, Vardarlı AT, Mutlu Z, Ulukuş M, et al. Identification of Y chromosome microdeletions in infertile Turkish men. Turkish journal of urology 2013;39:170.
25. Akbarzadeh Khiavi M, Jalili A, Safary A, Gharedaghchi Z, Mirinezhad SK, Mehdizadeh A, et al. Karyotypic abnormalities and molecular analysis of $\mathrm{Y}$ chromosome microdeletion in Iranian Azeri Turkish population infertile men. Systems Biology in Reproductive Medicine 2020;66:140-6.

26. Reijo R, Lee T-Y, Salo P, Alagappan R, Brown LG, Rosenberg $\mathrm{M}$, et al. Diverse spermatogenic defects in humans caused by $\mathrm{Y}$ chromosome deletions encompassing a novel RNAbinding protein gene. Nature genetics 1995;10:383-93. 